\title{
Association of body mass index, hand grip strength and quality of life with response to anti-tubercular therapy in adult patients of pulmonary and extra-pulmonary tuberculosis
}

\author{
Prashant Mishra ${ }^{1,2}$, Vipin Kumar Verma ${ }^{1}$, Meenakshi Meenu ${ }^{3}$, Anant Mohan ${ }^{4}$, \\ Jagriti Bhatia ${ }^{1}$, Dharamvir Singh Arya ${ }^{1 *}$
}

\author{
${ }^{1}$ Department of Pharmacology, All India Institute of Medical Sciences, New Delhi, India \\ ${ }^{2}$ Department of Pharmacology, Armed Force Medical College, Pune, Maharashtra, India \\ ${ }^{3}$ Department of Pharmacology, All India Institute of Medical Sciences, Bilaspur, Himachal Pradesh, India \\ ${ }^{4}$ Department of Pulmonary Medicine and Sleep Disorders, All India Institute of Medical Sciences, New Delhi, India
}

Received: 23 September 2021

Revised: 17 October 2021

Accepted: 18 October 2021

*Correspondence:

Dr. Dharamvir Singh Arya,

Email: dsarya16@gmail.com

Copyright: () the author(s), publisher and licensee Medip Academy. This is an open-access article distributed under the terms of the Creative Commons Attribution Non-Commercial License, which permits unrestricted non-commercial use, distribution, and reproduction in any medium, provided the original work is properly cited.

\begin{abstract}
Background: Monitoring of anti-tubercular therapy (ATT) response necessary for successful completion of ATT regimen. Presently available monitoring tools are invasive and have limitations. This study undertaken to see whether non-invasive tools like body mass index (BMI), hand grip strength (HGS) and quality of life (QOL) can serve as a reliable tool for monitoring ATT response.

Methods: The 50 patients of tuberculosis were monitored for BMI, HGS and QOL via WHOQOL-BREF questionnaire and analyzed at baseline, 2 months and 6 months of starting ATT.

Results: BMI HGS increased significantly at 2 months and 6 months compared to baseline with ATT. Physical and social domain of WHOQOL-BREF increased at 2 and 6 months with ATT, other domains shown no significant changes. Conclusions: Monitoring of BMI, handgrip strength and QOL can be a cost-effective tool for monitoring ATT response, both in pulmonary and extra pulmonary tuberculosis.
\end{abstract}

Keywords: Tuberculosis, BMI, HGS, WHOQOL-BREF, ATT

\section{INTRODUCTION}

As per the global TB report 2017 the estimated incidence of TB in India was approximately $28,00,000$ accounting for about a quarter of the world's TB cases. India have prepared a national strategic plan 2017-2025 with a goal to achieve a rapid decline in burden of $\mathrm{TB}$, morbidity and mortality while working towards elimination of TB in India by 2025 , five years ahead of global end TB targets. ${ }^{1}$

Wasting is a systemic clinical manifestation of TB, which may affect both the severity and outcome of the disease. ${ }^{2,3}$ In resource-limited country like India, non-invasive, easy to use with low running cost tools is the necessity of time for use in routine clinical care to determine the baseline severity and/or extent of disease and to monitor the response to $\mathrm{ATT}^{4}$ HGS is a simple, reliable and inexpensive assessment tool that has demonstrated prognostic utility. ${ }^{5}$ Although handgrip dynamometry is reliably prognostic, the test is rarely used during routine assessment in pulmonary diseases.

Apart from physical symptoms, a patient of tuberculosis faces several physiological, psychological, financial and social problems. These problems have a great impact on the well-being of the patient and impair the QOL of the 
patient suffering from tuberculosis. It has been recognized that QOL indices, which focus on patients' own perception of disease, provide additional information that cannot be obtained from conventional clinical and functional measurements. ${ }^{6}$ Therefore, for a comprehensive assessment of the patient under treatment of tuberculosis, certain questions need to be asked in terms of patient's perception of improvement, besides routine clinical, bacteriological and radiological assessments. The WHOQOL-BREF in Hindi appears to be a suitable instrument for comprehensively evaluating the QOL in health care settings in India.,

There are few tools available to aid early clinical judgment and decision-making. The ability to tailor treatment regimens to individual patients in a personalized medicinetype approach would be a major breakthrough in the clinical management of TB as well as for clinical trials and could potentially be achieved by monitoring of response to ATT through non-invasive, cheap, easy to use tools like BMI, HGS and QOL.

Studies suggest that deficits in weight and HGS among patients starting TB treatment are severe and also have analyzed the effect of food supplementation on these parameters. ${ }^{9,10}$ But most of these studies are either crosssectional or of shorter duration and have not assess the effect of ATT on these parameters in real life situation. These QOL parameters provides measurement of functioning and well-being rather than of diseases and disorders. ${ }^{11,12}$ The WHOQOL-BREF arises from 10 years of development research on QOL and health care. It is a person centered, multilingual instrument for subjective assessment and designed for generic use as multidimensional profile, so enabling a wide range of diseases and conditions to be compared and it is a crossculturally valid assessment of well-being, as reflected by its 4 domains: physical, psychological, social and environmental and its Hindi version, WHOQOL-BREF in Hindi appears to suitable instrument for comprehensively evaluating QOL in health care settings in India. ${ }^{7,8,13,15}$

Physical and mental distress is common in TB patients leading to poor disease outcome or poor treatment outcome because of decreased ability to take treatment. ${ }^{16,17}$ Knowing patient's health related QOL would enable program makers and clinicians to understand the functioning and well-being of $\mathrm{TB}$ patients so that individual patient specific needs are addressed to attain the best clinical/ treatment outcome and thus increasing the likelihood of adequate case management in TB programs.

Conventional clinical assessment may not be able to quantify the impairment of QOL in a patient, they risk reaching misleading conclusions about the effect of treatment on health status. ${ }^{18}$

This study was designed to determine the correlation between non-invasive tools of BMI, HGS and QOL with response to ATT in PTB and EPTB patients.

\section{METHODS}

The study was conducted at AIIMS, New Delhi from April 2019 to August 2020 after approval of institutional ethics committee. Study was conducted in 50 Patients and 25 healthy volunteers. It was a prospective observational comparative study. Adult outpatients visiting the DOTS center were screened as per following inclusion/ exclusion criteria and were prospectively recruited, after taking informed written consent:

\section{Inclusion criteria}

Patients who had further criteria can included in study- 1) Age $\geq 18$ years; 2) Male/female/other gender; 3) Newly diagnosed case of PTB or EPTB who have not been started on ATT regimen and 4) Willing to participate in the study.

\section{Exclusion criteria}

Patients who had further conditions can excluded from the study-1) Patients having co-infection with HIV; 2) Known case of chronic kidney disease, rheumatoid arthritis, coronary artery disease, diabetes mellitus, amyloidosis, bronchial asthma or any other chronic inflammatory/immunological disorder; 3) Patient on immunosuppressant/ anti-cancer drugs; 4) Patient having any musculoskeletal disorder affecting upper limb; 5) Patients taking any other drugs known to cause myopathy and 6) Pregnant women.

At baseline (after diagnosis but before start of ATT therapy): participants demographic profile, clinical features, lab/ radiological reports, diagnosis, treatment regimen plan were noted in a predesigned case record form. Baseline weight, height, HGS by using hand grip dynamometer and health related QOL score using WHOQOL-BREF questionnaire in Hindi were measured. All participants were followed up at 2-months (intensive phase end) and 6-months (continuous phase end) of initiation of ATT. At follow up visit, BMI, HGS and health related QOL scoring in tuberculosis were measured.

HGS in age and sex matched apparently with healthy volunteers $(n=25)$ for baseline comparison. Academic residents, staff and patient attendants were recruited.

Body weight was measured using electronic weighing scales. Height was measured using a stadiometer. BMI was calculated as weight in $\mathrm{kg} / \mathrm{square}$ of height in meter. HGS was measured using hand grip dynamometer. The measurements were carried out with the patient seated down and the arm flexed at $90^{\circ}$. Three readings were taken with each hand, alternating hands between measurements to avoid fatigue. Highest reading obtained with either hand was taken as the maximum HGS. Health related QOL scoring in tuberculosis was assessed using a WHOQOLBREF questionnaire in Hindi. The domain scores for the WHOQOL-BREF were computed and transformed to a 
scale of 0 to 100 , according to WHO. Higher domain scores reflect better QOL.

\section{Statistical analysis}

The data analysis was done using 'IBM SPSS statistics (version 23.0)'. Descriptive statistics using mean \pm SD for continuous variables or frequency and percentage for categorical variables were employed for describing the socio-demographic and clinical characteristics of the study participants. ANOVA with post hoc Bonferroni correction was used for comparison of data between baseline, 2- and 6-months within group analysis and one-way ANOVA with post hoc Bonferroni correction for comparison between PTB and EPTB. Effect of other variables on HGS and QOL domains were assessed by multiple linear regression. $\mathrm{p} \leq 0.05$ was considered as statistically significant. The detailed methodology has been depicted as flow chart (Figure 1).

\section{Schematic representation of study methodology}

\begin{tabular}{|l|}
\hline \multicolumn{1}{|c|}{ Screening of patients of TB as per inclusion and exclusion criteria } \\
\hline Group 1 (n=25): Pulmonary TB \\
At baseline (after diagnosis and before starting ATT): Patients demographic profile, clinical \\
features, lab / radiological reports, diagnosis, treatment regimen plan were noted in a \\
predesigned case record form. Weight, body mass index, hand grip strength by using hand \\
dynamometer and health related quality of life scoring using WHOQOL-BREF questionnaire in \\
Hindi were measured. \\
At 2 and 6 months after initiation of ATT: Body mass index, hand grip strength by using hand \\
grip dynamometer and health related quality of life scoring in tuberculosis using WHOQOL- \\
BREF questionnaire in Hindi were measured at each visit. Lab parameters and radiological \\
reports were noted from patients' available medical documents. \\
Hand grip strength by using hand grip dynamometer was measured in age and sex matched 25 \\
apparently healthy volunteers for baseline comparisons. \\
\hline All data was analyzed using Microsoft excel and SPSS version 23. \\
Numerical data was expressed as mean \pm standard deviation (SD). \\
Categorical data was presented as proportions. \\
\hline
\end{tabular}

Figure 1: Study methodology.

\section{RESULTS}

\section{Participant's enrollment}

A total of 25 patients with PTB and 25 patients with EPTB were enrolled in the study. Participants were followed-up on two subsequent (follow-up) visits at 2- and 6-months of commencement of ATT. Of these, 23 participants with pulmonary TB and 23 with EPTB completed the follow up visits and analysis was done considering these patients only (Figure 2).

\section{Demographic and baseline characteristics}

Age: The mean age of the study participants was $32.24 \pm 13.67$ years and $29.56 \pm 10.36$ years in PTB and EPTB group respectively. Amongst healthy volunteer group, the mean age of study participants was 29.92 \pm 7.39 .
Gender distribution: In PTB group, 26\%, $(\mathrm{n}=6)$ were female and $74 \%,(n=17)$ were males. The male was $43 \%$, $(\mathrm{n}=10)$ and females were $57 \%,(\mathrm{n}=13)$ in EPTB group (Table 1).

Occupation: Most of the participants were unemployed [43\%, $(n=10)$ in PTB group and $48 \%,(n=11)$ in ЕРTB group] and were dependent on their spouse or parents for livelihood (Table 1). These were mostly students and housewives (Table 1).

Clinical symptoms: Most common symptoms in PTB group were Cough (100\%), fever (74\%), weight loss (70\%), loss of appetite (57\%), dyspnoea (39\%) and haemoptysis $(39 \%)$. Whereas in EPTB group, fever $(65 \%)$, cough $(44 \%)$, enlarged lymph node $(35 \%)$ and weight loss $(30 \%)$ were more common presenting symptoms. 


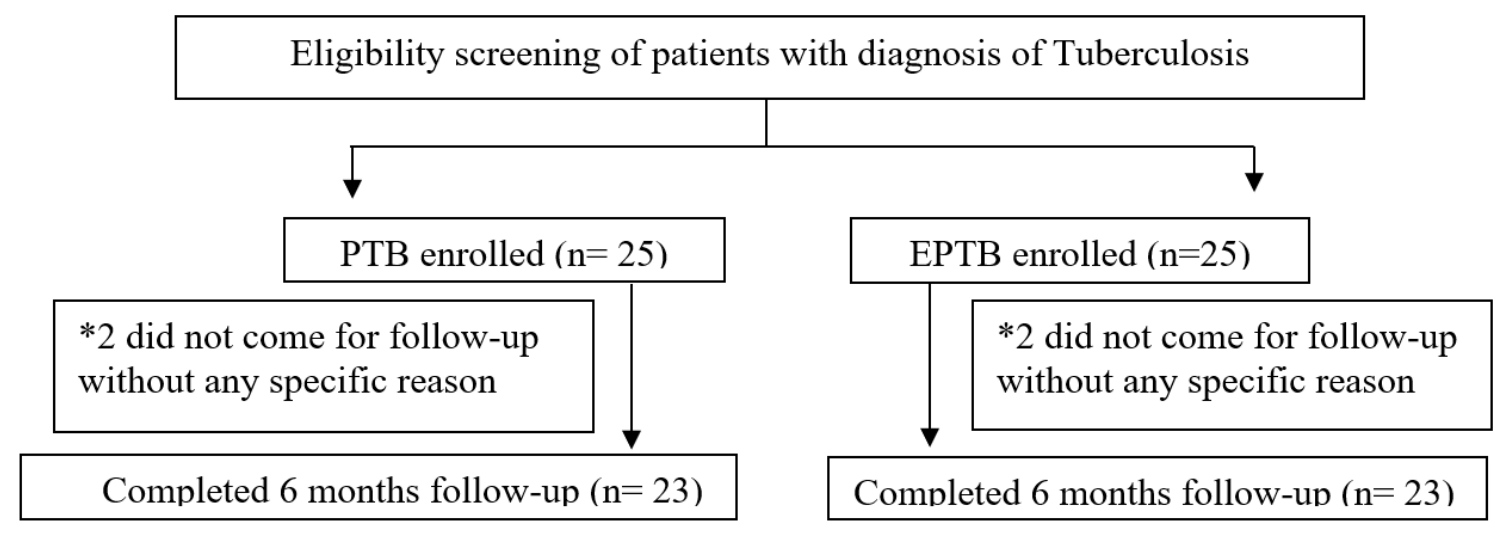

Figure 2: Disposition of patients.

Table 1: Baseline characteristics of participants.

\begin{tabular}{|c|c|c|c|c|c|c|}
\hline \multirow[b]{2}{*}{ Characteristics } & \multicolumn{2}{|c|}{ Pulmonary TB, $(\mathrm{n}=23)$} & \multicolumn{2}{|c|}{ Extra pulmonary TB, $(\mathrm{n}=\mathbf{2 3})$} & \multicolumn{2}{|c|}{ Healthy volunteer, $(\mathrm{n}=25)$} \\
\hline & $\begin{array}{l}\text { Mean/ } \\
\text { median }\end{array}$ & $\mathrm{SD} / \mathrm{IQR}$ & $\begin{array}{l}\text { Mean/ } \\
\text { median }\end{array}$ & $\mathrm{SD} / \mathrm{IQR}$ & $\begin{array}{l}\text { Mean/ } \\
\text { median }\end{array}$ & $\mathrm{SD} / \mathrm{IQR}$ \\
\hline Age (Years) & 30.96 & 12.83 & 29.56 & 10.59 & 29.92 & 7.39 \\
\hline BMI $\left(\mathrm{kg} / \mathrm{m}^{2}\right)$ & 20.06 & 3.76 & 21.94 & 4.33 & 25.07 & 4.35 \\
\hline HGS (kg) & 28.14 & 9.21 & 26.27 & 7.61 & 36.46 & 7.49 \\
\hline $\begin{array}{l}\text { Overall general health } \\
\text { (Scale 1-5) }\end{array}$ & 3 & $(2-3)$ & 2 & $(2-4)$ & \multirow[t]{2}{*}{ NA } & \\
\hline Overall QOL (Scale 1-5) & 3 & $(2-4)$ & 3 & $(2-4)$ & & \\
\hline Characteristics & $\mathbf{N}(\%)$ & & $\mathbf{N}(\%)$ & & $\mathbf{N}(\%)$ & \\
\hline \multicolumn{7}{|l|}{ Gender } \\
\hline Male & $17(73.91)$ & & $10(43.48)$ & & $14(56)$ & \\
\hline Female & $6(26.09)$ & & $13(56.52)$ & & $11(44)$ & \\
\hline \multicolumn{7}{|l|}{ Occupation } \\
\hline Teacher & $2(8.69)$ & & $1(4.35)$ & & $12(48)$ & \\
\hline Student & $6(26.09)$ & & $5(21.74)$ & & $8(32)$ & \\
\hline Labour & $2(8.69)$ & & $1(4.35)$ & & - & \\
\hline Pvt Job & $7(30.43)$ & & $8(34.78)$ & & $3(12)$ & \\
\hline Housewife & $4(17.39)$ & & $6(26.09)$ & & $1(4)$ & \\
\hline Govt Job & $2(8.69)$ & & $2(8.69)$ & & $1(4)$ & \\
\hline \multicolumn{7}{|l|}{ Smoking } \\
\hline No & 19 (82.61) & & $21(91.30)$ & & $20(80)$ & \\
\hline Yes & $4(17.39)$ & & $2(8.70)$ & & $5(20)$ & \\
\hline \multicolumn{7}{|l|}{ Diagnosis } \\
\hline Microbiologically confirmed & $16(69.56)$ & & $6(26.09)$ & & - & \\
\hline $\begin{array}{l}\text { Clinico-radiologically } \\
\text { diagnosed }\end{array}$ & $7(30.43)$ & & 17 (73.91) & & - & \\
\hline \multicolumn{7}{|l|}{ Treatment outcome } \\
\hline ATT completed & $16(69.56)$ & & $17(73.91)$ & & - & \\
\hline ATT extended & $7(30.43)$ & & $6(26.09)$ & & - & \\
\hline
\end{tabular}

IQR: Inter quartile range; SD: Standard deviation; TB: Tuberculosis

Diagnosis: The $70 \%,(\mathrm{n}=16)$ of the cases in PTB group were microbiologically confirmed by either sputum AFB positive or GeneXpert/CBNAAT of sputum/bronchoalveolar lavage (BAL) fluid. The $30 \%$, $(n=7)$ were clinicradiologically diagnosed on basis of clinical symptoms and radiological findings in chest X-ray/CT scan/MRI. Amongst EPTB group, 35\%, $(n=8)$ cases were of tubercular lymphadenitis, followed by tubercular pleural effusion $[26 \%(n=6)]$ and spinal TB [17\%, $(n=4)]$. Most of these cases were diagnosed on the basis of clinical feature and FNAC/biopsy findings of granulomatous lesions. Diagnosis of tubercular pleural effusion was made on basis of chest $\mathrm{x}$-ray findings and pleural fluid biochemical assessment. In abdominal tuberculosis and spinal tuberculosis, CT scan and MRI were the main diagnostic investigation. 
ATT regimen: All participants in $\mathrm{PTB}$ and $\mathrm{EPTB}$ group during study duration were given ATT as per existing national guidelines: -2HRZE with 4 HRE. Pyridoxine 25 $\mathrm{mg}$ was prescribed in few patients for prevention of peripheral neuritis.

Treatment outcome: The $70 \%,(\mathrm{n}=16)$ in PTB group and $74 \%,(n=17)$ in EPTB group completed ATT regimen. ATT regimen was extended beyond 6-months in $30 \%$, $(n=7)$ and $26 \%, \quad(n=6)$ in PTB and EPTB group respectively.

\section{Baseline characteristic}

The baseline characteristics and other demographic characteristics of participants are shown in Table 1.

\section{Changes in BMI, QOL domains and HGS in EPTB}

The changes in BMI, QOL domains and HGS at baseline, post-ATT 2- and 6-months in PTB and EPTB participants are shown in Table 2 and 3 respectively.

\section{$B M I$}

The mean BMI at baseline was $20.06 \pm 0.78 \mathrm{~kg} / \mathrm{m}^{2}$ and $21.94 \pm 0.90 \mathrm{~kg} / \mathrm{m}^{2}$ in PTB and ЕРTB group respectively. The mean BMI at 2- and 6-months of follow up in PTB group were significantly increased to $20.81 \pm 0.85 \mathrm{~kg} / \mathrm{m}^{2}$ $(\mathrm{p}<0.001)$ and $21.76 \pm 0.89 \mathrm{~kg} / \mathrm{m}^{2}(\mathrm{p}<0.001)$ respectively in comparison to baseline (Figure 3 and Table 2). In EPTB group, the mean BMI at 2- and 6-months of follow up were increased to $22.45 \pm 0.89 \mathrm{~kg} / \mathrm{m}^{2}(\mathrm{p}=0.078)$ and $23.19 \pm 0.87$ $\mathrm{kg} / \mathrm{m}^{2}(\mathrm{p}<0.001)$ respectively in comparison to baseline (Figure 3 and Table 3).

Table 2: Changes in BMI, QOL domains and HGS in pulmonary TB at various time points.

\begin{tabular}{|c|c|c|c|c|c|c|c|c|c|}
\hline \multirow{2}{*}{ Parameters } & \multirow{2}{*}{$\begin{array}{l}\text { Baseline } \\
\text { Mean } \pm \\
\text { SEM* }\end{array}$} & \multirow{2}{*}{$\begin{array}{l}2 \text { months } \\
\text { Mean } \pm \\
\text { SEM* }\end{array}$} & \multirow{2}{*}{$\begin{array}{l}6 \text { months } \\
\text { Mean } \pm \\
\text { SEM** }\end{array}$} & \multicolumn{2}{|c|}{$\begin{array}{l}\text { Baseline vs } 2 \\
\text { months }\end{array}$} & \multicolumn{2}{|c|}{$\begin{array}{l}\text { Baseline vs } 6 \\
\text { months }\end{array}$} & \multicolumn{2}{|c|}{2 vs 6 months } \\
\hline & & & & $\begin{array}{l}\text { Mean } \\
\text { diff }\end{array}$ & $\mathbf{P}$ & $\begin{array}{l}\text { Mean } \\
\text { diff }\end{array}$ & $\mathbf{P}$ & $\begin{array}{l}\text { Mean } \\
\text { diff }\end{array}$ & $\mathbf{P}$ \\
\hline BMI $\left(\mathrm{kg} / \mathrm{m}^{2}\right)$ & $20.06 \pm 0.78$ & $20.81 \pm 0.85$ & $21.76 \pm 0.89$ & $\begin{array}{l}-0.756 \\
(-1.16 \text { to } \\
-0.35)\end{array}$ & $<0.001$ & $\begin{array}{l}-1.69 \\
(-2.25 \text { to } \\
-1.25\end{array}$ & $<0.001$ & $\begin{array}{l}-0.94 \\
(-1.26 \text { to } \\
-0.63)\end{array}$ & $<0.001$ \\
\hline HGS (kg) & $28.14 \pm 1.92$ & $28.53 \pm 1.92$ & $30.86 \pm 1.97$ & $\begin{array}{l}-0.39 \\
(-1.83 \text { to } \\
1.05)\end{array}$ & 1.00 & $\begin{array}{l}-2.72 \\
(-4.14 \text { to } \\
-1.29)\end{array}$ & $<0.001$ & $\begin{array}{l}-2.33 \\
(-3.41 \text { to } \\
-1.25)\end{array}$ & $<0.001$ \\
\hline $\begin{array}{l}\text { Physical } \\
\text { domain }\end{array}$ & $\begin{array}{l}21.65 \pm 0.95 \\
(52.2 \pm 16.2)\end{array}$ & $\begin{array}{l}24.13 \pm 0.82 \\
(61.4 \pm 12.9)\end{array}$ & $\begin{array}{l}27.0 \pm 0.59 \\
(71.26 \pm 10)\end{array}$ & $\begin{array}{l}-2.48 \\
(-4.00 \\
\text { to }-0.95\end{array}$ & 0.001 & $\begin{array}{l}-5.35 \\
(-7.41 \text { to } \\
-3.28)\end{array}$ & $<0.001$ & $\begin{array}{l}-2.87 \\
(-4.51 \\
\text { to }-1.23)\end{array}$ & $<0.001$ \\
\hline $\begin{array}{l}\text { Psychological } \\
\text { domain }\end{array}$ & $\begin{array}{l}19.83 \pm 0.93 \\
(58.5 \pm 18.4)\end{array}$ & $\begin{array}{l}20.61 \pm 0.72 \\
(60.6 \pm 13.8)\end{array}$ & $\begin{array}{l}21.96 \pm 0.50 \\
(66.65 \pm 10.55)\end{array}$ & $\begin{array}{l}-0.78 \\
(-2.09 \text { to } \\
0.53)\end{array}$ & 0.410 & $\begin{array}{l}-2.13 \\
(-4.23 \text { to } \\
-0.04)\end{array}$ & 0.045 & $\begin{array}{l}-1.35 \\
(-3.12 \text { to } \\
0.23)\end{array}$ & 0.185 \\
\hline $\begin{array}{l}\text { Social } \\
\text { relationships }\end{array}$ & $\begin{array}{l}10.00 \pm 0.37 \\
(58.4 \pm 14.8)\end{array}$ & $\begin{array}{l}10.39 \pm 0.32 \\
(62 \pm 13.80)\end{array}$ & $\begin{array}{l}10.91 \pm 0.22 \\
(66.65 \pm 9.01)\end{array}$ & $\begin{array}{l}-0.39 \\
(-1.13 \text { to } \\
0.35)\end{array}$ & 0.557 & $\begin{array}{l}-0.91 \\
(-1.99 \text { to } \\
0.166)\end{array}$ & 0.118 & $\begin{array}{l}-0.522 \\
(-1.32 \text { to } \\
0.27)\end{array}$ & 0.31 \\
\hline Environment & $\begin{array}{l}23.17 \pm 0.70 \\
(49.3 \pm 10.8)\end{array}$ & $\begin{array}{l}23.61 \pm 0.64 \\
(50.0 \pm 10.4)\end{array}$ & $\begin{array}{l}25.09 \pm 0.46 \\
(54.69 \pm 6.66)\end{array}$ & $\begin{array}{l}-0.43 \\
(-1.51 \text { to } \\
0.64)\end{array}$ & 0.923 & $\begin{array}{l}-1.91 \\
(-3.2 \text { to } \\
-0.63)\end{array}$ & 0.003 & $\begin{array}{l}-1.48 \\
(-2.78 \text { to } \\
-0.18)\end{array}$ & 0.023 \\
\hline Overall QOL & $3.04 \pm 0.23$ & $3.48 \pm 0.15$ & $3.74 \pm 0.16$ & $\begin{array}{l}-0.43 \\
(-0.89 \text { to } \\
0.02)\end{array}$ & 0.065 & $\begin{array}{l}-0.69 \\
(-1.41 \text { to } \\
0.02)\end{array}$ & 0.060 & $\begin{array}{l}-0.26 \\
(-0.78 \text { to } \\
0.26)\end{array}$ & 0.623 \\
\hline $\begin{array}{l}\text { Overall } \\
\text { quality of } \\
\text { health }\end{array}$ & $2.56 \pm 0.21$ & $3.52 \pm 0.16$ & $3.83 \pm 0.17$ & $\begin{array}{l}-0.96 \\
(-1.40 \text { to } \\
-0.51)\end{array}$ & $<0.001$ & $\begin{array}{l}-1.26 \\
(-1.96 \text { to } \\
-0.56)\end{array}$ & $<0.001$ & $\begin{array}{l}-0.30 \\
(-0.85 \\
\text { to } 0.25)\end{array}$ & 0.49 \\
\hline
\end{tabular}

Repeated measures ANOVA with post hoc Bonferroni correction, *Transformed to 0-100 scale.

\section{$H G S$}

The mean HGS at baseline was $28.14 \pm 1.92 \mathrm{~kg}$ and $26.27 \pm 1.59 \mathrm{~kg}$ in PTB group and EPTB group respectively. In comparison to age and sex matched healthy volunteers, there is a mean HGS deficit of $8.32 \mathrm{~kg}$ in PTB and $10.19 \mathrm{~kg}$ in EPTB group. The mean HGS at 2and 6-months of follow up in PTB group were increased to $28.53 \pm 1.92 \mathrm{~kg}(\mathrm{p}=1.00)$ and $30.86 \pm 1.97 \mathrm{~kg} \quad(\mathrm{p}<0.001)$ respectively in comparison to baseline (Figure 4, Table 2). In EPTB group, the mean HGS at 2- and 6-months of follow up were increased to $26.63 \pm 1.53 \mathrm{~kg}(\mathrm{p}=0.442)$ and $27.57 \pm 1.5 \mathrm{~kg}(\mathrm{p}<0.001)$ respectively in comparison to baseline (Figure 4 and Table 3 ).

\section{Effects of other variables on HGS using multiple linear regression analysis}

Multiple linear regression analysis was performed with HGS as dependent variable. Age, gender, state, occupation, smoking, alcohol and tobacco status were kept in model as predictor variable. The model was found to be 
significant $\left[\mathrm{F}(7,43)=6.92 ; \mathrm{R}^{2}=0.463, \mathrm{p}<0.001\right]$. Gender and alcohol intake may affect HGS. When gender is changed from male to female, the HGS changes by 0.678 unit times and alcohol intake history from negative to positive, the HGS changes by 0.280 -unit times (Table 4).

Table 3: Changes in BMI, QOL domains and HGS in extra pulmonary TB at various time points.

\begin{tabular}{|c|c|c|c|c|c|c|c|c|c|}
\hline \multirow{2}{*}{ Parameters } & \multirow{2}{*}{$\begin{array}{l}\text { Baseline } \\
\text { Mean } \pm \\
\text { SEM* }\end{array}$} & \multirow{2}{*}{$\begin{array}{l}2 \text { months } \\
\text { Mean } \pm \\
\text { SEM* }\end{array}$} & \multirow{2}{*}{$\begin{array}{l}6 \text { months } \\
\text { Mean } \pm \\
\text { SEM } *^{*}\end{array}$} & \multicolumn{2}{|c|}{$\begin{array}{l}\text { Baseline vs } 2 \\
\text { months }\end{array}$} & \multicolumn{2}{|c|}{$\begin{array}{l}\text { Baseline vs } 6 \\
\text { months }\end{array}$} & \multicolumn{2}{|c|}{2 vs 6 months } \\
\hline & & & & $\begin{array}{l}\text { Mean } \\
\text { diff }\end{array}$ & $\mathbf{P}$ & $\begin{array}{l}\text { Mean } \\
\text { diff }\end{array}$ & $\mathbf{P}$ & $\begin{array}{l}\text { Mean } \\
\text { diff }\end{array}$ & $\mathbf{P}$ \\
\hline $\begin{array}{l}\text { BMI } \\
\left(\mathrm{kg} / \mathrm{m}^{2}\right)\end{array}$ & $21.94 \pm 0.90$ & $22.45 \pm 0.89$ & $23.19 \pm 0.87$ & $\begin{array}{l}-0.50 \\
(-1.05 \text { to }- \\
0.04\end{array}$ & 0.078 & $\begin{array}{l}-1.25 \\
(-1.84 \text { to } \\
-0.67\end{array}$ & $<0.001$ & $\begin{array}{l}-0.75 \\
(-1.02 \text { to } \\
0.48)\end{array}$ & $<0.001$ \\
\hline HGS (kg) & $26.27 \pm 1.59$ & $26.63 \pm 1.53$ & $27.57 \pm 1.5$ & $\begin{array}{l}-0.36 \\
(-0.995 \text { to } \\
0.265)\end{array}$ & 0.442 & $\begin{array}{l}-1.30 \\
(-1.89 \text { to } \\
-0.71)\end{array}$ & $<0.001$ & $\begin{array}{l}-0.94 \\
(-1.45 \text { to }- \\
0.43)\end{array}$ & $<0.001$ \\
\hline $\begin{array}{l}\text { Physical } \\
\text { health }\end{array}$ & $\begin{array}{l}21.26 \pm 0.96 \\
(50.0 \pm 17.2)\end{array}$ & $\begin{array}{l}23.56 \pm 0.80 \\
(61.43 \pm 12.97)\end{array}$ & $\begin{array}{l}27.65 \pm 0.51 \\
(71.26 \pm 10)\end{array}$ & $\begin{array}{l}-2.30 \\
(-4.28 \text { to }- \\
0.33)\end{array}$ & 0.019 & $\begin{array}{l}-6.39 \\
(-8.49 \text { to } \\
-4.28)\end{array}$ & $<0.001$ & $\begin{array}{l}-4.08 \\
(-5.57 \text { to }- \\
2.60)\end{array}$ & $<0.001$ \\
\hline $\begin{array}{l}\text { Psycho- } \\
\text { logical }\end{array}$ & $\begin{array}{l}18.65 \pm 0.78 \\
(58.5 \pm 18.4)\end{array}$ & $\begin{array}{l}20.08 \pm 0.65 \\
(60.65 \pm 13.83)\end{array}$ & $\begin{array}{l}21.96 \pm 0.48 \\
(66.6 \pm 10.5)\end{array}$ & $\begin{array}{l}-1.44 \\
(-2.67 \text { to }- \\
0.19)\end{array}$ & 0.02 & $\begin{array}{l}-3.30 \\
(-4.6 \text { to } \\
-2.00)\end{array}$ & $<0.001$ & $\begin{array}{l}-1.87 \\
(-3.06 \text { to }- \\
0.68)\end{array}$ & 0.002 \\
\hline $\begin{array}{l}\text { Social } \\
\text { relationships }\end{array}$ & $\begin{array}{l}9.39 \pm 0.32 \\
(58.4 \pm 14.8)\end{array}$ & $\begin{array}{l}9.61 \pm 0.22 \\
(62 \pm 13.80)\end{array}$ & $\begin{array}{l}9.96 \pm 0.22 \\
(66.6 \pm 9.01)\end{array}$ & $\begin{array}{l}-0.22 \\
(-0.83 \text { to } \\
0.39)\end{array}$ & 1.00 & $\begin{array}{l}-0.56 \\
(-1.27 \text { to } \\
0.14)\end{array}$ & 0.151 & $\begin{array}{l}-0.35 \\
(-0.83 \text { to } \\
0.13)\end{array}$ & 0.218 \\
\hline Environment & $\begin{array}{l}21.83 \pm 0.82 \\
(49.3 \pm 10.8)\end{array}$ & $\begin{array}{l}22.56 \pm 0.62 \\
(50.04 \pm 10.43)\end{array}$ & $\begin{array}{l}23.56 \pm 0.60 \\
(54.69 \pm 6.6)\end{array}$ & $\begin{array}{l}-0.74 \\
(-1.90 \text { to } \\
0.43)\end{array}$ & 0.344 & $\begin{array}{l}-1.74 \\
(-2.99 \text { to } \\
-0.49)\end{array}$ & 0.005 & $\begin{array}{l}-1.00 \\
(-1.85 \text { to }- \\
0.15)\end{array}$ & 0.017 \\
\hline Overall QOL & $3.08 \pm 0.18$ & $3.56 \pm 0.12$ & $3.83 \pm 0.08$ & $\begin{array}{l}-0.48 \\
(-0.75 \text { to }- \\
0.20)\end{array}$ & 0.001 & $\begin{array}{l}-0.74 \\
(-1.14 \text { to } \\
-0.33)\end{array}$ & $<0.001$ & $\begin{array}{l}-0.26 \\
(-0.55 \text { to } \\
0.03)\end{array}$ & 0.091 \\
\hline $\begin{array}{l}\text { Overall } \\
\text { quality of } \\
\text { health }\end{array}$ & $2.78 \pm 0.19$ & $3.48 \pm 0.12$ & $3.69 \pm 0.12$ & $\begin{array}{l}-0.69 \\
(-1.11 \text { to }- \\
0.28)\end{array}$ & 0.001 & $\begin{array}{l}-0.91 \\
(-1.49 \text { to } \\
-0.33)\end{array}$ & 0.002 & $\begin{array}{l}-0.22 \\
(-0.62 \text { to } \\
0.18)\end{array}$ & 0.512 \\
\hline
\end{tabular}

Repeated measures ANOVA with post hoc Bonferroni correction, *Transformed to 0-100 scale.

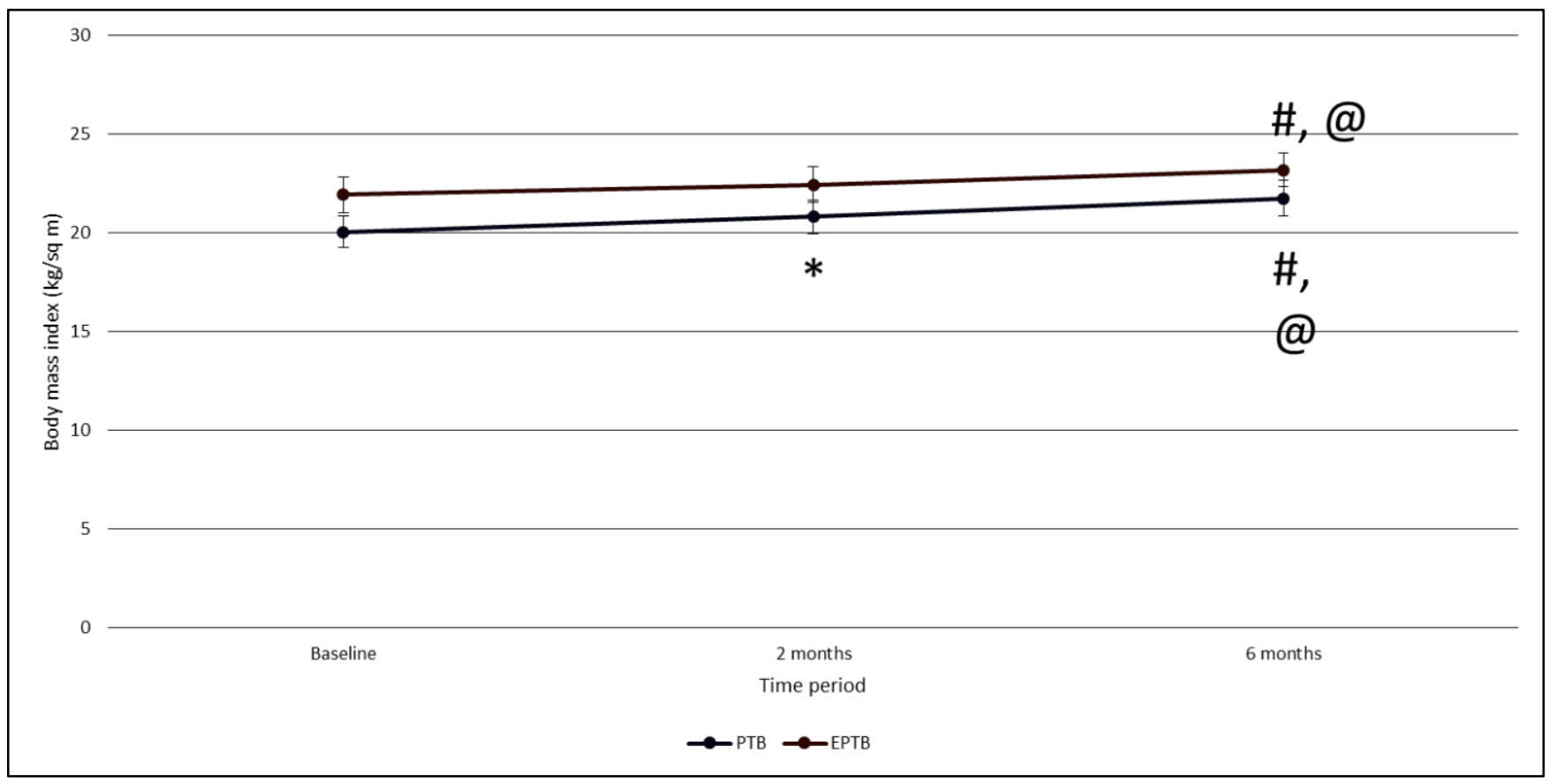

Figure 3: Change in BMI $\left(\mathrm{kg} / \mathrm{m}^{2}\right)$ at various time points in PTB and EPTB group.

Baseline vs 2 months ( $<<0.001$; \# Baseline vs 6 months ( $<<0.001)$; @ 2 vs 6 months $(\mathrm{p}<0.001)$. 


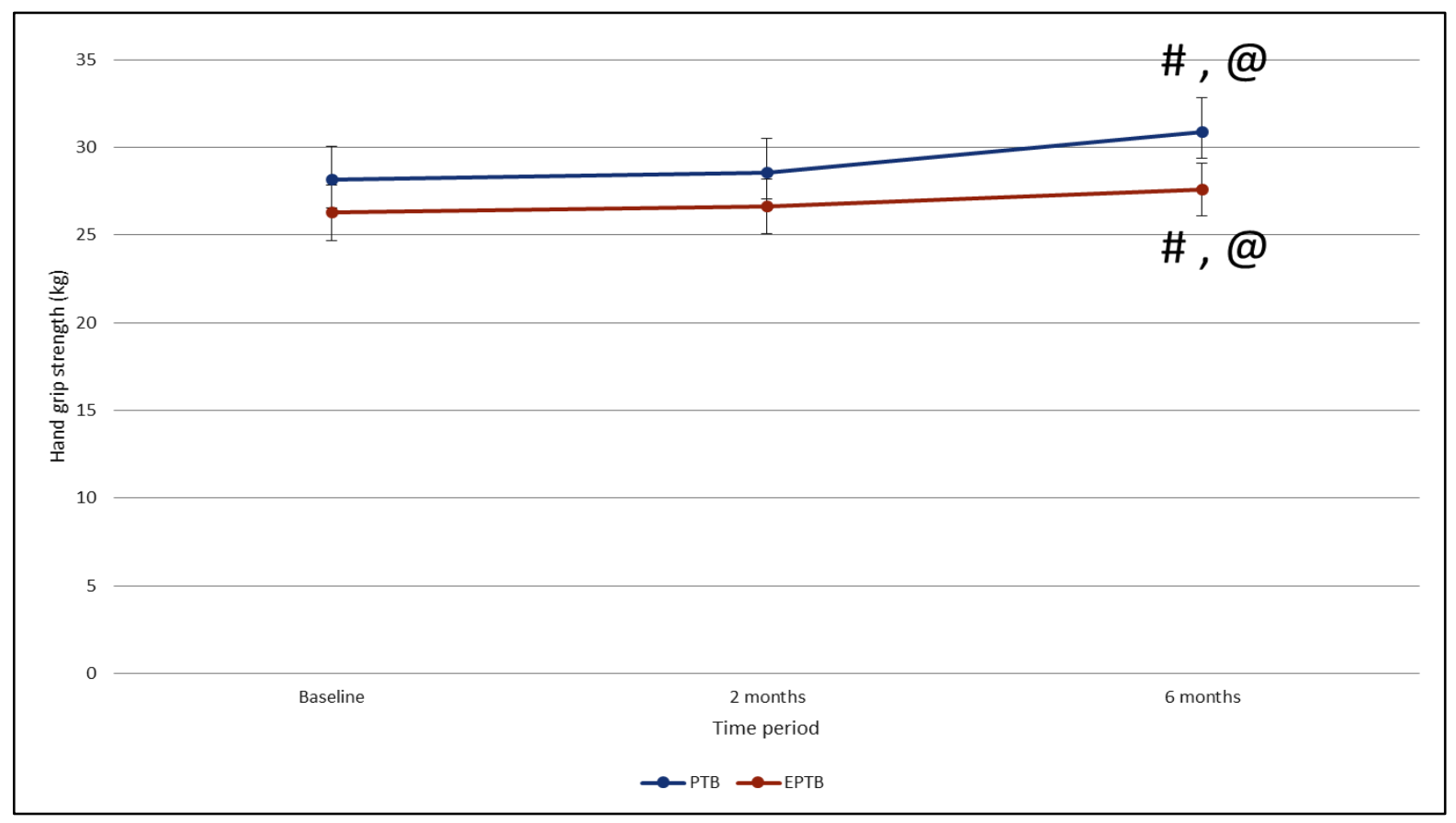

Figure 4: Change in HGS (kg) at various time points in PTB and EPTB group. \#Baseline vs 6 months ( $<<0.001)$; @ 2 vs 6 months ( $\mathrm{p}<0.001)$.

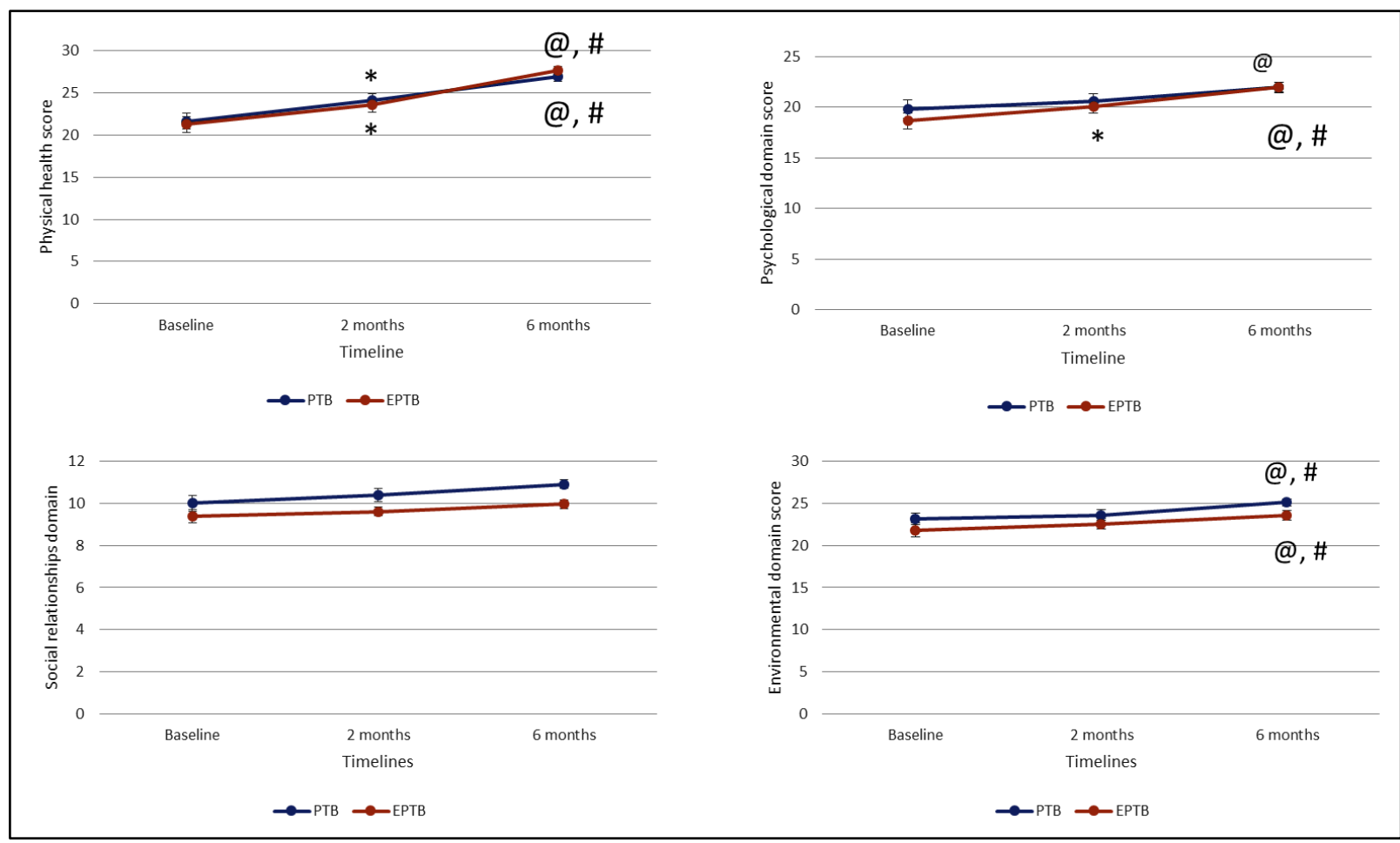

Figure 5: Changes in quality-of-life domains at various time points in PTB and EPTB group. *Baseline vs 2 months; @ Baseline vs 6 months; \# 2 months vs 6 months

\section{QOL domains}

QOL was measured using WHOQOL-BREF questionnaire. There was no statistically significant difference in the overall QOL with ATT in PTB but was statistically significant in EPTB group at 2-months $(\mathrm{p}=0.001)$ and 6 -months $(\mathrm{p}<0.001)$ post ATT in comparison to baseline. The overall quality of health improved significantly at 2-months (PTB p<0.001; EPTB $\mathrm{p}=0.001)$ and 6 months (PTB $\mathrm{p}<0.001$; EPTB $\mathrm{p}=0.002)$ post ATT in comparison to baseline. The raw scores of 
QOL domains in PTB and EPTB were transformed to 0100 scale as shown in Table 3 and 4 respectively.

\section{Physical health domain}

Physical health domain score improved significantly at 2months (EPTB $\mathrm{p}=0.02$ ) and 6-months (PTB $\mathrm{p}=0.045$; EPTB $\mathrm{p}<0.001)$ in comparison to baseline. Changes in scores were also significant at 6-months in comparison to 2-months, both in PTB and EPTB group (Table 2, 3 and Figure 5).

\section{Psychological domain}

Psychological domain score improved significantly at 2months (PTB $\mathrm{p}=0.001$; EPTB $\mathrm{p}=0.019$ ) and 6 months (PTB $\mathrm{p}<0.001$; EPTB $\mathrm{p}<0.001)$ in comparison to baseline. Change in scores were also significant at 6-months in comparison to 2-months in EPTB $(\mathrm{p}=0.002)$ (Table 2, 3 and Figure 5).

\section{Social relationships}

The changes in social relationships score were not statistically significant at 2- and 6-months in comparison to baseline, both in PTB and EPTB group (Table 2, 3 and Figure 5).

\section{Environment domain}

Environment domain score improved significantly at 6months (PTB $\mathrm{p}=0.003$; EPTB $\mathrm{p}=0.005$ ) in comparison to baseline. Change in scores were also significant at 6months in comparison to 2-months in PTB $(\mathrm{p}=0.023)$ and EPTB $(\mathrm{p}=0.017)($ Table 2, 3 and Figure 5).

\section{Comparison of QOL domains and HGS between PTB and} $E P T B$

On comparison of HGS between PTB and EPTB group, there was statistically significant increase in HGS at 6 months $(\mathrm{p}=0.024)$ in PTB (Table 5). No significant difference between PTB and EPTB group seen on comparing the QOL domains between PTB and EPTB (Table 5).

Table 4: Effects of other variable on HGS using multiple linear regression analysis coefficients.

\begin{tabular}{|c|c|c|c|c|c|}
\hline \multirow{2}{*}{ Model } & \multicolumn{2}{|c|}{ Unstandardized coefficients } & \multirow{2}{*}{$\begin{array}{l}\text { Standardized coefficients } \\
\text { Beta }\end{array}$} & \multirow{2}{*}{$\mathbf{T}$} & \multirow{2}{*}{ Sig. } \\
\hline & B & Std. error & & & \\
\hline Constant & 19.312 & 3.835 & & 5.035 & 0.000 \\
\hline Age (Years) & -0.048 & .096 & -.067 & -0.502 & 0.618 \\
\hline Gender & 11.927 & 2.047 & .678 & 5.827 & 0.000 \\
\hline State & -0.038 & .727 & -.006 & -0.052 & 0.959 \\
\hline Occupation & 0.525 & .654 & .089 & 0.803 & 0.427 \\
\hline Smoking & -2.659 & 3.498 & -.110 & -0.760 & 0.452 \\
\hline Alcohol & 6.432 & 2.958 & .280 & 2.174 & 0.036 \\
\hline Tobacco & -7.447 & 4.123 & -.211 & -1.806 & 0.078 \\
\hline
\end{tabular}

Dependent variable: HGSB

Table 5: Comparison of QOL and HGS between pulmonary and extra pulmonary group at various time points.

\begin{tabular}{|c|c|c|c|c|c|c|}
\hline \multirow{2}{*}{ Characteristics } & \multicolumn{2}{|l|}{ Baseline vs 2 months } & \multicolumn{2}{|l|}{ Baseline vs 6 months } & \multicolumn{2}{|l|}{2 months vs 6 months } \\
\hline & Mean diff & P value & Mean diff & P value & Mean diff & P value \\
\hline Physical health & $-0.17(-2.11$ to 1.76 & 0.857 & $1.04(-1.25$ to 3.34$)$ & 0.364 & $1.22(-0.50$ to 2.94$)$ & 0.160 \\
\hline Psychological & $0.65(-0.752$ to 2.05$)$ & 0.354 & $1.17(-0.74$ to 3.09$)$ & 0.224 & $0.52(-1.14$ to 2.18$)$ & 0.530 \\
\hline $\begin{array}{l}\text { Social } \\
\text { relationships }\end{array}$ & $-0.17(-0.92$ to 0.57$)$ & 0.641 & $-0.35(-1.35$ to 0.65$)$ & 0.489 & $-0.17(0.89$ to 0.54$)$ & 0.630 \\
\hline Environment & $0.30(-0.93$ to 1.54$)$ & 0.622 & $-0.17(-1.57$ to 1.22$)$ & 0.803 & $-0.48(-1.69$ to 0.73$)$ & 0.429 \\
\hline Overall QOL & $0.04(-0.37$ to 0.46$)$ & 0.834 & $0.04(-0.59$ to 0.68$)$ & 0.892 & $0.00(-0.46$ to 0.46$)$ & 1.00 \\
\hline $\begin{array}{l}\text { Overall quality } \\
\text { of health }\end{array}$ & $-0.26(-0.73$ to 0.21$)$ & 0.272 & $-0.35(-1.05$ to 0.36$)$ & 0.327 & $-0.09(-0.61$ to 0.44$)$ & 0.742 \\
\hline HGS & $-0.03(-1.25$ to 1.120$)$ & 0.966 & $-1.41(-2.62$ to -0.2$)$ & 0.024 & $-1.39(-2.32$ to -0.4$)$ & 0.005 \\
\hline
\end{tabular}

One-way ANOVA with post hoc Bonferroni correction

\section{DISCUSSION}

Weight gain after effective chemotherapy for tuberculosis has been reported by earlier researchers. ${ }^{19,20}$ Surprisingly, the mean BMI at baseline was $20.06 \pm 0.78 \mathrm{~kg} / \mathrm{m}^{2}$ and $21.94 \pm 0.90 \mathrm{~kg} / \mathrm{m}^{2}$ in PTB group and EPTB group respectively, which falls within the normal BMI range as per Asian criteria. ${ }^{21}$ The mean BMI at 2 and 6 months follow up in PTB and EPTB group were significantly increased to $20.81 \pm 0.85 \mathrm{~kg} / \mathrm{m}^{2}(\mathrm{p}<0.001)$ and $21.76 \pm 0.89$ $\mathrm{kg} / \mathrm{m}^{2}(\mathrm{p}<0.001)$ respectively in comparison to baseline. In 
EPTB group, the mean BMI at 2- and 6-months of follow up were also increased to $22.45 \pm 0.89 \mathrm{~kg} / \mathrm{m}^{2}(\mathrm{p}=0.078)$ and

$23.19 \pm 0.87 \mathrm{~kg} / \mathrm{m}^{2} \quad(\mathrm{p}<0.001)$ respectively $\mathrm{W} . \quad \mathrm{R} . \quad \mathrm{T}$. baseline. The data suggests BMI to be a good marker for monitoring treatment response and overall better nutritional status of the participants.

HGS can serve as an indirect indicator of overall muscle strength. In PTB group, there was increase in HGS of 2.72 $\mathrm{kg}$ from baseline after 6-months of ATT in comparison to $1.3 \mathrm{~kg}$ increase in HGS in EPTB. This increase in HGS is less in comparison to increase seen in other studies, may be due to difference in ethnicity and baseline nutritional status/nutritional support to participants. ${ }^{22,23}$ Hence, Nutritional support and dietary advice may be necessary to facilitate the reversal of deficit and treatment outcomes in patients of tuberculosis.

Amongst the QOL domains, physical health significantly increased at end of intensive and continuous phase of ATT, both in PTB and EPTB. Significantly increase in psychological domain score seen at 6-months of ATT in PTB, whereas after 2-months in EPTB. No significant increase seen in social relationships domain in PTB and EPTB. Significant increase at 6-months in PTB and EPTB was observed in environmental health domain. Similar findings were observed in various other studies with physical functioning domain affected more severely than others. $^{24-28}$ The greatest improvement in QOL seems to occur within the initial 2-3 months of therapy. ${ }^{24}$ A study from South India reported improvement in patient perceptions about physical and mental wellbeing after treatment. ${ }^{29}$ In a study from northern India, QOL improved significantly at end of intensive phase, and further at end of treatment. ${ }^{30}$ A study from Iraq that longitudinally used a TB-specific QOL questionnaire, physical and functional well-being, and the total QOL scores were significantly increased after two months of ATT. ${ }^{31}$ All QOL subscales, except social and economic well-being and spiritual wellbeing, improved at end of treatment, and the total QOL score had a statistically significant contribution towards predicting likelihood of favorable response to ATT. In a study from Yemen, both physical and mental summary scores improved at end of intensive phase of treatment. ${ }^{32}$ While the former improved further at treatment completion, the latter remained largely static, with mean scores still below population norms. In a study from Indonesia, 94\% patients showed a clinically significant improvement in SGRQ scores after two months of treatment, and $80 \%$ achieved additional significant improvement by end of treatment at six months. ${ }^{33}$ Progressive improvement across all QOL domains was also reported among patient data from Malaysia, Uganda and patients receiving ATT. ${ }^{34-36}$ In studies from South Africa, QOL improved significantly during treatment and at treatment completion, with biggest gains in the physical health scores. ${ }^{37,38}$ No socio-demographic traits were significantly associated with this improvement, suggesting that TB treatment was the principal determinant of change in QOL. Maximum improvements were seen in physical, followed by psychological domain. Also, lower education level and poor socioeconomic status viz. associated with greater impairment of QOL. ${ }^{39,40}$

This study, from India, looks into the relevance and utility of easily administrable tools of BMI, HGS and QOL as a reliable, inexpensive objective tool for regular monitoring of ATT therapy in both PTB and EPTB, so that timely interventions are instituted at risk patients.

\section{Limitations}

The study had some limitations. Nutritional history of the participants was not considered which may have influence on the HGS and QOL. The patients were followed only at three time points. The adherence to ATT by the patients were confirmed verbally and was presumed as they were getting treatment under DOTS center supervision. Measurement of serum concentration of ATT drugs and more frequent follow-up could have given better association between measured parameters.

\section{CONCLUSION}

This study provides basis for consideration of BMI, HGS and QOL score as adjunctive non-invasive, easily administrable, universal and cost-effective composite tool for treatment monitoring of ATT in out-patient department like DOT center settings. It will also provide a more holistic practical approach to monitor the effect of ATT as well as effectiveness and usefulness of nutritional supplementation plans for TB patients, initiated by government from time to time. HGS and QOL assessment using WHOQOL-BREF questionnaire can be used as an adjunct outcome measure for patients treated under the RNTCP.

\section{Funding: No funding sources \\ Conflict of interest: None declared \\ Ethical approval: The study was approved by the Institutional Ethics Committee}

\section{REFERENCES}

1. Central TB division Directorate General of Health Services, India TB report 2018. Ministry of Health and Family Welfare: New Delhi, India. 2018.

2. Van-Crevel R, Karyadi E, Netea MG. Decreased plasma leptin concentrations in tuberculosis patients are associated with wasting and inflammation. J Clin Endocrinol Metab. 2002;87:758-63.

3. Van-Lettow M, Van-der Meer JW, West CE. Interleukin-6 and human immunodeficiency virus load, but not plasma leptin concentration, predict anorexia and wasting in adults with pulmonary tuberculosis in Malawi. J Clin Endocrinol Metab. 2005;90:4771-6. 
4. Walzl G, Ronacher K, Hanekom W. Immunological biomarkers of tuberculosis. Nat Rev Immunol. 2011;11:343-54.

5. Bohannon RW. Hand-grip dynamometry predicts future outcomes in aging adults. J Geriatr Phys Ther. 2008;31:3-10.

6. Letrait M, Laurie A, Bean K. The asthma impact record (AIR) index: a rating scale to evaluate the quality of life of asthmatic patients in France. Eur Resp J. 1996;9:1163.

7. Saxena S, Chandiramani K, Bhargava R. WHOQOLHindi: A questionnaire for assessing quality of life in health care settings in India. World Health Organization Quality of Life. Natl Med J India. 1998;11:160-5.

8. Sathvik BS, Parthasarathi G, Narahari MG. An assessment of the quality of life in hemodialysis patients using the WHOQOL-BREF questionnaire. Indian J Nephrol. 2008;18:141-9.

9. Praygod G, Range N, Faurholt-Jepsen. Weight, Body Composition and Hand grip Strength among Pulmonary Tuberculosis Patients: A Matched CrossSectional Study in Mwanza, Tanzania. Trans R Soc Trop Med Hyg. 2011;105:140-7.

10. Martins N, Morris P, Kelly P. Food Incentives to Improve Completion of Tuberculosis Treatment: Randomized Controlled Trial in Dili, Timor-Leste. Bri Med J. 2009;339b:42-8.

11. Skevington SM, Lotfy M, O'Connell KA. WHOQOL Group. The World Health Organization's WHOQOLBREF quality of life assessment: Psychometric properties and results of the international field trial. A report from the WHOQOL group. Qual Life Res. 2004;13:299-310.

12. Mears DC, Velyvis JH, Chang CP. Displaced acetabular fractures managed operatively: Indicators of outcome. Clin Orthop Relat Res. 2003;173-86.

13. Pacian A, Kulik TB, Pacian J, Chrusciel P, Zolnierczuk-Kieliszek D, Jarosz MJ. Psychosocial aspect of quality of life of Polish women with breast cancer. Ann Agric Environ Med. 2012;19:509-12.

14. Khosravi A, Ramezani MA, Toghianifar N, Rabiei K, Jahandideh M, Yousofi A. Association between hypertension and quality of life in a sample of Iranian adults. Acta Cardiol. 2010;65:425-30.

15. De Oliveira, PP, Sandrin CC, Batista PH, Marinheiro LP, Wender, MC, Roisenberg F. Relationship between quality of life and vertebral fracture in older women living in Southern Brazil. Rev Bras Ginecol Obstet. 2011;33:231-7.

16. Rajeswari R, Balasubramanian R, Muniyandi M, Geetharamani S, Thresa X, Venkatesan P. Socioeconomic impact of tuberculosis on patients and family in India. Int $\mathbf{J}$ Tuberc Lung Dis. 1999;3(10):869-77.

17. Liefooghe R, Michiels N, Habib S, Moran MB, De Muynck A. Perception and social consequences of tuberculosis: a focus group study of tuberculosis patients in Sialkot, Pakistan. Soc Sci Med. 1995;41(12):1685-92.
18. Guyatt GH, King DR, Feeny DH, Stubbing D, Goldstein RS. Generic and specific measurement of health-related quality of life in a clinical trial of respiratory rehabilitation. $\mathrm{J}$ Clin Epidemiol. 1999;52(3):187.

19. Harries AD, Nkhoma WA, Thompson PJ, Nyangulu DS, Wirima JJ. Nutritional status in Malawian patients with pulmonary tuberculosis and response to chemotherapy. Eur J Clin Nutr. 1988;42:445-50.

20. Kennedy N, Ramsay A, Uiso L, Gutmann J, Ngowi FI, Gillespie SH. Nutritional status and weight gain in patients with pulmonary tuberculosis in Tanzania. Trans R Soc Trop Med Hyg. 1996;90:162-6.

21. Wen CP, David Cheng TY, Tsai SP. Are Asians at greater mortality risks for being overweight than caucasians? Redefining obesity for Asians. Public Health Nutr. 2009;12:497-506.

22. De Reus YA, Beek LT, Werf TSVD, Akkerman OW. Changes in body composition and strength during initial treatment in malnourished patients with tuberculosis. Eur Resp J. 2019;PA5277.

23. White LV, Lee N, Marin FP, Saludar NR, Edwards T, Cox SE. Performance of alternative measures to body mass index in the assessment of moderate and severe under-nutrition among acutely unwell patients hospitalized in a TB ward in the Philippines: A crosssectional study. PLoS one. 2019;14(5):e0215968.

24. Bauer M, Leavens A, Schwartzman K. A systematic review and meta-analysis of the impact of tuberculosis on health-related quality of life. Qual Life Res. 2013;22(8):2213-35.

25. Chamla D. The assessment of patients' health-related quality of life during tuberculosis treatment in Wuhan, China. Int J Tuberc Lung Dis. 2004;8(9):1100-6.

26. Dhuria M, Sharma N, Ingle G. Impact of tuberculosis on the quality of life. Ind. J Comm. Med, 2008;33(1):58-9.

27. Chung WS, Lan YL, Yang MC. Psychometric testing of the short version of the world health organization quality of life (WHOQOL-BREF) questionnaire among pulmonary tuberculosis patients in Taiwan. BMC Pub Health. 2012;12:630.

28. Kastien-Hilka T, Abulfathi A, Rosenkranz B, Bennett B, Schwenkglenks M, Sinanovic E. Health-related quality of life and its association with medication adherence in active pulmonary tuberculosis- a systematic review of global literature with focus on South Africa. Health Qual Life Outcomes. 2016;14:42.

29. Rajeswari R, Muniyandi M, Balasubramanian R, Narayanan PR. Perceptions of tuberculosis patients about their physical, mental and social well-being: a field report from south India. Soc Sci Med. 2005;60(8):1845-53.

30. Dar SA, Shah NN, Wani ZA, Nazir D. A prospective study on quality of life in patients with pulmonary tuberculosis at a tertiary care hospital in Kashmir, Northern India. Ind J Tuberc. 2019;66(1):118-22.

31. Dujaili JA, Sulaiman SA, Hassali MA, Awaisu A, Blebil AQ, Bredle JM. Health related quality of life as 
a predictor of tuberculosis treatment outcomes in Iraq. Int J Infect Dis. 2015;31:4-8.

32. Jaber AA, Khan AH, Syed Sulaiman SA, Ahmad N, Anaam MS. Evaluation of health-related quality of life among tuberculosis patients in two cities in yemen. PLoS One. 2016;11(6):e0156258.

33. Maguire GP, Anstey NM, Ardian M, Waramori G, Tjitra E, Kenangalem E. Pulmonary tuberculosis, impaired lung function, disability and quality of life in a high-burden setting. Int $\mathbf{J}$ Tuberc Lung Dis. 2009;13(12):1500-6.

34. Atif M, Sulaiman SA, Shafie AA, Asif M, Sarfraz MK, Low HC. Impact of tuberculosis treatment on health-related quality of life of pulmonary tuberculosis patients: a follow-up study. Health Qual Life Outcomes. 2014;12:19.

35. Babikako HM, Neuhauser D, Katamba A, Mupere E. Feasibility, reliability and validity of health-related quality of life questionnaire among adult pulmonary tuberculosis patients in urban Uganda: cross-sectional study. Health Qual Life Outcomes. 2010;8:93.

36. Kisaka SM, Rutebemberwa E, Kasasa S, Ocen F, Nankya-Mutyoba J. Does health related quality of life among adults with pulmonary tuberculosis improve across the treatment period? A hospital-based crosssectional study in Mbale Region, Eastern Uganda. BMC Res Notes. 2016;9(1):467.
37. Kastien-Hilka T, Rosenkranz B, Sinanovic E, Bennett $\mathrm{B}$, Schwenkglenks M. Health related quality of life in South African patients with pulmonary tuberculosis. PLoS One. 2017;12(4):e0174605.

38. Louw JS, Mabaso M, Peltzer K. Change in healthrelated quality of life among pulmonary tuberculosis patients at primary health care settings in South Africa: a prospective cohort study. PLoS One. 2016;11(5):e0151892.

39. Unalan D, Soyuer F, Ceyhan O, Basturk M, Ozturk A. Is the quality of life different in patients with active and inactive tuberculosis? Indian $\mathrm{J}$ Tuberc. 2008;55(3):127-37.

40. Duyan V, Kurt B, Aktas Z, Duyan GC, Kulkul DO. Relationship between quality of life and characteristics of patients hospitalized with tuberculosis. Int J Tuberc Lung Dis. 2005;9(12):13616.

Cite this article as: Mishra $\mathrm{P}$, Verma VK, Meenu M, Mohan A, Bhatia J, Arya DS. Association of body mass index, hand grip strength and quality of life with response to anti-tubercular therapy in adult patients of pulmonary and extra-pulmonary tuberculosis. Int J Basic Clin Pharmacol 2021;10:1297-307. 